\title{
नНTPODONOГКЯ KYतDTYPDI
}

\author{
КАНАТЬЕВА Наталья Сергеевна \\ кандидат биологических наук, \\ доцент кафедры мировой экономики и финансов \\ Астраханского государственного университета, \\ Астрахань, Российская Федерация \\ Natalya S. KANATYEVA \\ Cand. Sci. (Hydrobiology), Assoc. Prof., \\ Astrakhan State University, \\ Astrakhan, Russian Federation, \\ nessy71@mail.ru
}

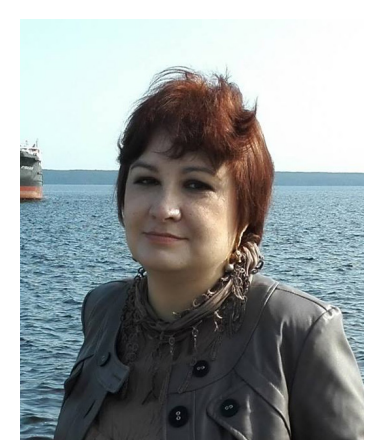

\section{Маргинализация старообрядчества к середине XIX века: происхождение Белокриницкой иерархии}

\section{The Marginalisation of the Old Believers by the Mid-19th Century: The Origin of the Belokrinitskaya Hierarchy}

В статье утверждается тезис о постепенной маргинализации старообрядчества - русского религиозного течения, возникшего после церковных реформ 1653-1667 гг., называемых расколом. Одной из главнейших проблем, возникших у старообрядцев, было прерывание трёхчинной иерархии и, как следствие, отсутствие легитимного священства. Попытки восстановить иерархию различными путями осуществлялись вплоть до 1846 г., когда к старообрядчеству согласился присоединиться боснийский митрополит Амвросий. О некоторых обстоятельствах этого присоединения рассказано в статье. В ней также доказывается, что большинство в старообрядчестве не признало легитимность присоединения Амвросия (по нескольким причинам), и делается вывод о том, что, стремясь к восстановлению «нормальной церковной жизни», старообрядцы принимали решения и совершали поступки, демонстрирующие нарастающую маргинализацию древлеправославного сообщества и усугубляющие противоречия внутри него.

Ключевые слова: старообрядчество, маргинализация, трёхчинная иерархия, беглопоповщина, митрополит, симония, единоверие. 
Раскол русской православной церкви 1653-1667 гг., инициированный царём Алексеем Михайловичем и воплощённый патриархом Никоном, официально затянулся на долгих 250 лет, до Указа об укреплении начал веротерпимости императора Николая II, подписанного 17 апреля 1905 г. За эти годы старообрядцы, то есть те, кто не принял «новин» Никона, прошли трудный путь. В зависимости от личности правителя государства, им приходилось умирать за веру и покидать родину, гореть на кострах самосожжений и создавать форпосты цивилизации в безлюдных местах, платить двойную пошлину и носить особую одежду, скрываться для исполнения богослужений и искать епископа за рубежом. Все эти действия старообрядцев были продиктованы, в первую очередь, верностью вере прадедов, «жаждой полноценной церковной жизни» (С. А. Зеньковский) и, в дальнейшем, попытками приспособиться к жизни в государстве, где себя они ощущали чужими, а верховные власти - враждебными.

Оставив в стороне рассуждения о том, что недальновидные действия череды царствовавших привели к противостоянию государственной власти и тех, кто всегда являлся опорой трону - людей консервативных и обеспеченных, заострим внимание на положении этих самых консерваторов, невольно оказавшихся оппозиционерами. С самого начала раскола старообрядчество не было единым, и это усугубляло возрастающую маргинализацию людей, не принявших реформы Никона.

Вспомним классическое определение понятия «маргинализация», пришедшее из социологии: это явление, «обозначающее промежуточность, „пограничность “положения человека между какими-либо социальными группами». Более точно маргинализацию можно описать как «процесс (выделение моё. - H. К.) разрушения гражданского общества, проявляющийся в распаде социальных групп, разрыве традиционных связей между людьми, потере индивидами объективной принадлежности к той или иной социальной общности, извращение этических, эстетических, правовых, физиологических и иных общечеловеческих норм и ценностей...» [5]. Этот процесс в той или иной степени и в то или иное время начался в старо- обрядчестве. Рассмотрим это утверждение на одном из самых ярких примеров.

Главнейшая проблема старообрядчества заключалась в отсутствии легитимного священства. Павел, епископ Коломенский и Каширский, был последним епископом, которого возвели в сан (хиротонисали) до реформ патриарха Никона. Он же оставался и единственным епископом, который этих «новин» не принял. После его смерти в 1656 г., трагической (официальная версия - утонул или растерзан дикими зверями) или насильственной (старообрядческая версия - сожжён в срубе по приказу Никона), старообрядцы на 180 лет, до присоединения в 1846 г. боснийского митрополита Амвросия (оставим пока в стороне обстоятельства этого присоединения), оказались лишены полноты трёхчинной иерархии.

Вспомним, что церковная иерархия состоит из трёх основных степеней священнослужителей: это архиереи, или епископы, пресвитеры, или священники, и диаконы. Это и носит название трёхчинной иерархии и считается важнейшей и неотъемлемой частью апостольской преемственности. Поэтому наличие трёхчинности так важно для каноничного устройства, а иногда даже и для самого существования церкви. Главной особенностью трёхчинной иерархии является то, что только архиереи (епископы) имеют право рукополагать (хиротонисать) новых священнослужителей. Нет епископов - нет новых священников.

И вот, естественным ходом времени и волей властей предержащих, священство дораскольного поставления ушло. Как писал в «Истории о бегствующем священстве» известный старообрядческий деятель, писатель и историк Иван Алексеев-Стародубский, «и тако таковых иереов тама преста быти» $[1, \mathrm{c}$. 9]. Новое священство рукополагать было некому. Именно по этой причине с самого начала раскола старообрядцы были озабочены поисками епископов, готовых перейти (или, как говорили сами старообрядцы, «вернуться») в староверие. Однако ряд попыток, предпринятых в XVIII в., со всей присущей старообрядцам изобретательностью и привлечением немалых ресурсов, как людских, так и материальных, успеха не имел. 
Вначале старообрядцам приходилось довольствоваться паллиативными мерами. Путём убеждения, уговоров, а иногда и подкупа им довольно долго удавалось переманивать из господствовавшей церкви священников и диаконов. Разумеется, подобный путь обретения иерархии не находил понимания у властей. Кроме того, далеко не вся старообрядческая община одобрила такой способ появления священства, и, в свою очередь, уже среди приверженцев древлеправославия произошёл раскол. Именно так появилось обширное старообрядческое согласие - поповцы, или беглопоповцы. Остальная часть общины, не принявшая подобного священства, стала именоваться беспоповщиной.

Представители беглопоповской части старообрядчества принимали священников и диаконов, переходящих («бегствующих») от новообрядческой церкви, повторным крещением: «Приходящих убо от Великороссии новокрещёных повторяху своим крещением...» $[1$, c. 14]. Но были беглопоповские общины, которые принимали «бегствующих» через миропомазание [8]. Такие принципиальные разногласия в приёме опять привели к раздроблению, теперь уже беглопоповщины, на несколько толков.

А вскоре последовали жёсткие правительственные меры по пресечению «священноделательной» миссии старообрядцев. Вначале, в 1822 г., «совращение в раскол» было запрещено императором Александром I. Позднее, в 1830-1840 гг., императором Николаем I были дополнительно приняты меры, направленные на уничтожение старообрядческого «бегствующего» священства. В своей книге «Краткая история древлеправославной (старообрядческой) церкви» Ф. Е. Мельников называет это время «николаевским оскудением священства» [6, с. 182].

Что было делать? Оставалось только искать помощи за рубежом. На московском соборе старообрядцев-поповцев было принято решение об организации епископской кафедры за границей. В 1846 г. в старообрядческую церковь был принят боснийский митрополит Амвросий и учреждена Австрийская, или Белокриницкая, иерархия, получившая название по месту пребывания - городку Белая Криница, входившему в состав Австро-Венгрии.

Амвросий был далеко не первым архиереем, к которому обращались посланцы старообрядцев. В разные времена, начиная с 1712 г., когда из важнейшего старообрядческого центра Ветки было направлено прошение к Иерусалимскому патриарху Хрисанфу, с просьбой о хиротонии во епископа некоего инока Игнатия, и до 70-х гг. XVII в., когда старообрядцы пытались обратиться за помощью к Греческому митрополиту Евсевию, древлеправославные общины стремились вернуть трёхчинную иерархию. Обращались старообрядцы и к русским архиереям, в частности, к Тихону Задонскому, Палладию Рязанскому, Иоанникию Коломенскому [8]. Всё было безуспешно.

И вот нашёлся, наконец, архиерей, согласившийся принять старообрядчество. Но долгожданное появление митрополита явилось радостным событием для одной части старообрядцев и досадной неприятностью для другой. Начнём с того, что примерно половина древлеправославных, в том числе Московская Преображенская и Петербургская общины, митрополита Амвросия не приняла, предпочитая оставаться в беспоповщине. Влиятельнейший центр старообрядчества Керженец, средоточие скитов и старообрядческих святынь, очень долго не мог прийти к единому мнению - принимать или не принимать Амвросия. Сомнение вызывало крещение Амвросия, совершённое не погружением, а обливанием. Для многих старообрядцев Амвросий так и остался «обливанцем». Более того, старообрядцы-поповцы приняли митрополита Амвросия вторым чином, через миропомазание, заронив при этом еще больше сомнений у паствы, ведь миро, сохранявшееся со времен патриарха Иосифа, последнего дораскольного патриарха, признаваемого старообрядцами, «по нужде» разбавлялось водой, так как нового взять было неоткуда: «миро древнее окончася, о чём пространное имеется послание» (диакона Александра, известного старообрядческого деятеля и оратора. - H. К.) [1, с. 17]. До времен присоединения Амвросия это миро дошло уже прозрачным.

Подобная практика приема священников (и тем более - митрополита) из официаль- 
ной церкви путём миропомазания, искажающая самый смысл таинства хиротонии, была неприемлема и для многих видных членов старообрядческих общин. На одном из старообрядческих соборов, проходившем на знаменитой Рогожке (Рогожском кладбище в Москве, являвшемся центром поповщинской общины) в 1779 г., против этого активно выступал старообрядческий монах Никодим. Чиноприему Амвросия также был посвящен особый старообрядческий собор. Он состоялся на той же самой Рогожке 27 октября 1846 г., и там, после бурных прений, жарких обсуждений и взаимных претензий, вопрос о принятии Амвросия в старообрядчество вторым чином миропомазания все же решился утвердительно.

Виднейший теоретик и деятель старообрядчества Ксенос (Иларион Егорович Кабанов), автор «Окружного послания», писал об австрийском священстве и его родоначальнике следующее: «Корень его гнил и основание не твердо» [2, с. 24]. Еще определеннее высказался австрийский епископ Аркадий: «Церковь наша вся на случайных правилах, а врат не имать, т. е. обдержныя правила празднуют. Разсмотрим и самый корень, Амвросия не вратами, но теснотою, с нуждою великою... Но если по обдержным (легитимным. - Н. К.) правилам разсмотреть нашу всю церковь, то едва ли что в ней останется незыблемо». И далее: «Владыко святый, если бы на сей хартии открыл вам Амвросиев недостатки... Но открыть не на пользу, разве когда потребуется надобность. Амвросий принят по великой нужде, а не по обдержным правилам, если по обдержным правилам поверять всех (наших) святителей достоинство, то затворите и церкви все» $[7$, c. 109, 139].

Нельзя не упомянуть о чрезвычайно неприглядной истории, сопровождавшей присоединение Амвросия к старообрядчеству. Дело в том, что ходили упорные слухи о его небескорыстии: якобы митрополит принял решение о переходе потому, что ему просто заплатили. И немало - речь шла о 500 золотых червонцах. (Золотые червонцы середины XIX в. по своему весу размеру и пробе в точности соответствовали царским золотым десятирублевкам, имевшим хождение с 1897 г., по так называемому «золотому стандарту» Витте, действовавшему до Первой мировой войны; то есть 500 червонцев были равны 5000 царских рублей. Правда, нужно заметить, говорили всё же не о русских червонцах, а об австрийских - см. ниже.) Вот что пишет комментатор на сайте Русской Древлеправославной церкви (до 1923 г. - беспоповской): «В статье «Симония» мы рассмотрели ряд материалов, относящихся к договору между белокриницкими депутатами и митрополитом Амвросием, однако в истории о 500 червонцах фигурируют еще два документа. Так называемые секретные условия, написанные по отдельности митрополитом Амвросием и белокриницкими депутатами. Мы не стали рассматривать эти документы в упомянутой статье по причине того, что их подлинность категорически отрицается белокриницкими апологетами, мы, в свою очередь, также не утверждаем их подлинности. Однако каждый, кто интересуется вопросом Белокриницкой иерархии, должен все же сам иметь возможность сделать необходимые выводы, а не полагаться лишь на мнение защитников Белокриницкой иерархии. Коль белокриницкие апологеты имели возможность рассмотреть эти документы и подвергнуть их критике, следовательно, и мы должны иметь такую возможность» [4].

Далее на сайте приводится документ, называемый «Секретное условие от имени депутатов от 15 апреля 1846 г.», где, в частности, есть такие фразы: «Его высокопреосвященство (Амвросий. - H. К.) будет жить в Белой Кринице, в нашем монастыре, на всем монастырском содержании; сверх же того монастырь обязуется давать его высокопреосвященству жалованье в каждый год 500 червонцев австрийскаго золота, пока он жив будет, с тем чтобы исполнять все по правилам святых отец, согласно монастырскаго устава, без нарушения. Притом же обязуется монастырь дать его родному сыну г. Георгию Поповичу кошт на дорогу до Боснии и обратно на привезение своей жены оттуда; еще купить ему в Белой Кринице дом, с принадлежащим ему двором и огородом, в вечную его собственность. Однако, если по кратком или долгом времени случится его высокопреосвященству Божьим изволением, по общему долгу человечества, смерть, тогда обязуется монастырь наградить 
его, г. Георгия, за службу родителя, отца его, удовольствовать его судя по обстоятельствам и благоразсуждению монастыря» [4].

Второй документ, с не менее откровенными формулировками, якобы принадлежит перу самого Амвросия, он называется «Условие от имени митрополита Амвросия от 15 апреля 1846 г.». В нём написано буквально следующее: «Я, нижеподписавшийся, боснийский митрополит Амвросий Попович, заключил сие условие с австрийскими верноподданными буковинскими жителями Алимпием Милорадовым и Павлом Васильевым в том, что согласился я поступить в староверческую религию верховным пастырем надо всеми духовными и мирскими людьми, состоящими в староверческой религии. По прибытии в Белокриницкий монастырь принять по долгу христианскому духовнаго отца из тамошних священников и учинить то, что будет предлагать мне духовник необходимое в присоединении церковном, согласно соборным правилам св. отец, а потом поставить себе в наместники другаго епископа из белокриницкаго духовенства, а самому мне до смерти жить в том монастыре и получать жалованья в год по пятисот червонцев австрийским золотом, и, пока буду жив, обязуюсь исполнять правила святых отец без нарушения и монастырский весь устав по их обряду, а монастырь обязан перевезти на свой счет из Боснии роднаго моего сына Георгия Поповича и его жену Анну Николаевну и купить им в Белокринице в вечную собственность дом, с двором и огородом, в тысячу червонных, а в случае смерти моей, Амвросия, вознаградить их от монастыря по усмотрению, но не менее тысячи червонных, в чем и подписуюсь. Боснийский митрополит Амвросий.

Уполномоченные Белокриницкаго монастыря депутаты Алимпий и Павел клялись митрополиту в верности исполнения условия пред св. Евангелием и целовали оное» [4].

Как мы можем видеть, эти документы не оставляют никакого сомнения в этой истории с «купленным» митрополитом. Разумеется, сразу возникает вопрос об их аутентичности, подлинности. Как эти документы, будучи столь важными и тайными, стали доступны?

В 1865 г. к православию, на условиях единоверия, перешли от Белокриницкой митро- полии несколько весьма высокопоставленных священнослужителей. Среди них были такие значимые в старообрядчестве личности, как Онуфрий, наместник митрополита и епископ Браиловский, Пафнутий, епископ Коломенский, а также секретарь Белокриницкой митрополии архидиакон Филарет. Перешли они не с пустыми руками. Перебежчики предоставили профессору Субботину, известнейшему миссионеру-теоретику Русской православной церкви, преподававшему на кафедре истории и обличения русского раскола в Московской духовной академии, архив Белокриницкого монастыря. Очевидно, какой важностью обладали подлинные документы, свидетельствовавшие о том, как была учреждена Белокриницкая иерархия. Эти бесценные бумаги бывшие белокриницкие иерархи дополнили несколькими беседами с Субботиным, и в результате в 1874 г. Субботин издал труд, названный им «История Белокриницкой иерархии».

В наши задачи не входит подробный разбор этих документов, приведение доказательств их подлинности или, наоборот, сфальсифицированности. Достаточно и намёка на то, что они были, чтобы зародить сомнения в легитимности Белой Криницы. Тем более что епископ Браиловский Онуфрий, перейдя в единоверие, стал простым монахом и оставался таковым до самой смерти, то есть корысти в переходе у него не было никакой, да и славился он всю жизнь крайним благочестием и набожностью. Если подобный высокопоставленный церковнослужитель решается на такой шаг, логично предположить, что он имеет к тому веские основания, в данном случае - знание о происхождении Белокриницкой иерархии.

Итак, впервые появившийся почти за 200 лет отсутствия митрополит не признавался большинством (на тот период) старообрядцев, причём среди этого большинства находились высокообразованные и уважаемые в сообществе люди. Но, по довольно лукавой старообрядческой формуле, «по нужде и пременение (изменение. - H. К.) закона бывает».

Митрополит Амвросий, пробывший весьма непродолжительное время в чине, успел сделать главное - он рукоположил во епископа уставщика Киприана Тимофеева, во чине Кирилла, который в дальнейшем смог 
рукополагать священников. Преемство возобновилось. А сам Амвросий был заключён под стражу в монастырь в Цилле австрийским императором, по требованию императора русского. В монастырском заключении он и скончался. В 1996 году на Всемирном соборе старообрядцев Белокриницкого согласия Амвросий был причислен к лику святых. По мнению посетителя сайта «Древлеправославие» под ником Хорхе, «идеализация митрополита Амвросия - это прямое следствие отхода от традиционализма, вековых сломов под никонианство поповщины и понижение интеллектуального уровня его избирателей, который (уровень. H. К.) к 1846 году (год признания Белокриниц- кой иерархии. - Н. К.) уже полностью отошел от духовной культуры первых старообрядцев» [3].

Таким образом, пример приобретения старообрядцами митрополита, после длительного отсутствия и прерывания трёхчинной иерархии, вполне отчётливо показывает продолжающуюся в XIX в. маргинализацию старообрядческого сообщества. «Жажда нормальной церковной жизни», по выражению С. А. Зеньковского, толкала отчаявшихся сторонников древлеправославия, утверждавших, что «умрём за аз единый», не только на «пременение» закона, но и на полукриминальные способы утверждения священства.

\section{Natalya S. KANATYEVA \\ The Marginalisation of the Old Believers by the Mid-19th Century: The Origin of the Belokrinitskaya Hierarchy}

Abstract. The Raskol ("split") of the Russian Orthodox Church in 1653-1667, initiated by Tsar Aleksey Mikhailovich and realised by Patriarch Nikon, went on for 250 years until Nicholas II signed a decree On Tolerance Development on 17 April 1905. Over those years, the Old Believers had come a hard way. Since the beginning of the Raskol, the Old Believers' Community had not been unified, which caused the marginalisation of those, who did not accept Nikon's reforms. The key problem of the Old Believers was a lack of a legitimised priesthood. Pavel, bishop of Kolomna and Kashira, was the last bishop ordained before Nikon's reforms and the only one who had not accepted the novelties. After his death in 1656, the Old Believers found themselves without a full three-pronged hierarchy. There was no one to ordain a new priesthood. Thus, since the beginning of the Raskol, the Old Believers had been seeking bishops who were ready to turn to Old Belief. Some of their attempts, made in the 18th century, failed. First Old Believers had to content with palliative measures. They managed to draw over priests and deacons in a variety of ways. However, not all Old Believers supported such a way of the priesthood formation. And soon a new split followed among Old Belief adepts: a new broad creed appeared, Popovtsy or Beglopopovtsy; and a part of the community that did not accept such a priesthood, Bezpopovtsy. This way of acquiring the hierarchy was not approved by the authorities. In 1822 and in the 1830s-1840s, Alexander I and Nicholas I took measures to destroy the fleeing priesthood of Old Believers. At the Moscow Assembly of the Popovtsy, a decision was made to create a bishop diocese abroad. In 1846, Ambrose, metropolitan of Bosnia, became an Old Believer, and a hierarchy of Austria or Belaya Krinitsa was introduced; the latter was a town belonging to Ausria-Hungary. Ambrose's conversion to Old Belief occurred amid unsavory circumstances. There were rumours on his covetousness: as if the metropolitan made his decision after he had been paid. The amount mentioned was 500 chervontsy of "Austrian gold". However, despite most of the Old Believers' doubts and protests, including those of respected figures from the Old Believers' clergy and clergy centres' representatives, Ambrose was converted. In 1865, several high-rank clergymen from the Metropolis of Belaya Krinitsa became Orthodox, and handled the archive of the Monastery of Belaya Krinitsa to Professor Subbotin, a missioner, a theorist of the Russian Orthodox Church. The documents were about the establishment of the Belaya Krinitsa priesthood. On the basis of the documents, Subbotin published A History of the Belaya Krinitsa Priesthood in 1874. The Metropolitan's conversion reflects the Old Believers' marginalisation in the 19th century. The "thirst for normal church life" had led the supporters of Old Belief to marginal ways of priesthood formation. 
Keywords: Old Believers, marginalisation, three-pronged hierarchy, Beglopopovshchina, metropolitan, simony, Edinoverie.

\section{Использованная литература:}

1. Алексеев (Стародубский) И. История о бегствующем священстве. М.: Археодоксия, 2005.

2. Братское слово. 1875. Часть 1-я.

3. Митрополит Амвросий: жизнь и смерть [Электронный ресурс] // Древлеправославие. URL: https://txt. drevle.com/mirrors/drevlepravoslavie-2012.10.23/data/ t00000000204.html (дата обращения 20.06.19).

4. Ещё немного о 500 червонцах [Электронный ресурс] // Религиозная организация Русская Древлеправославная Церковь. URL: http://raoc.info/articles/161esche-nemnogo-o-500-chervoncah.html (дата обращения 20.06.19).

5. Маргинализация [Электронный ресурс] // Словари и энциклопедии на Академике. URL: https:// dic.academic.ru/dic.nsf/ruwiki/656803 (дата обращения 20.06.19).

6. Мельников Ф. Е. Краткая история древлеправославной (старообрядческой) церкви. Барнаул: Изд-во БГПУ, 1999.

7. Субботин Н. И. Переписка раскольнических деятелей. (Материалы для истории белокриницкого священства). Вып. 2. Письма Аркадия Славского, Илариона Егоровича Кабанова (Ксеноса) и др. М.: Тип. Э. Лисснера и Ю. Романа, 1889.

8. Русская Православная старообрядческая Церковь (РПсЦ). URL: https://ruvera.ru/rpsc (дата обращения 20.06.19).

\section{References:}

1. Alekseev, I. (2005) Istoriya o begstvuyushchem svyashchenstve [The Story of the Fleeing Priesthood]. Moscow: Arkheodoksiya.

2. Bratskoe slovo. (1875) Part 1.

3. Drevlepravoslavie. (2012) Mitropolit Amvrosiy: zhizn' $i$ smert' [Metropolitan Ambrose: Life and Death]. [Online] Available from: https://txt.drevle.com/mirrors/ drevlepravoslavie-2012.10.23/data/t00000000204.html. (Accessed: 20.06.2019).

4. Russian Old-Orthodox Church. (n.d.) Eshche nemnogo o 500 chervontsakh [A Little More About 500 Chervonetsy]. [Online] Available from: http://raoc.info/ articles/161-esche-nemnogo-o-500-chervoncah.html. (Accessed: 20.06.2019).

5. Dic.academic.ru. (n.d.) Marginalizatsiya [Marginalisation]. [Online] Available from: https:// dic.academic.ru/dic.nsf/ruwiki/656803 . (Accessed: 20.06.2019).

6. Mel'nikov, F.E. (1999) Kratkaya istoriya drevlepravoslavnoy (staroobryadcheskoy) tserkvi [A Brief History of the Old-Orthodox (Old Believer) Church]. Barnaul: Barnaul SPU*.

7. Subbotin, N.I. (1889) Perepiska raskol'nicheskikh deyateley. (Materialy dlya istorii belokrinitskogo svyashchenstva) [Correspondence of Schismatic Figures. (Materials for the History of the Belaya Krinitsa Priesthood)]. Is. 2. Moscow: Tip. E. Lissnera i Yu. Romana.

8. Russian Orthodox Old-Rite Church. [Online] Available from: https://ruvera.ru/rpsc. (Accessed: 20.06.2019). (In Russian).

\section{Полная библиографическая ссылка на статью:}

Канатьева, Н. С. Маргинализация старообрядчества к середине XIX века: происхождение Белокриницкой иерархии [Электронный ресурс] / Н. С. Канатьева // Наследие веков. - 2019. - № 4. - C. 66-72. DOI: 10.36343/SB.2019.20.4.008

\section{Full bibliographic reference to the article:}

Kanatyeva, N. S. (2019) The Marginalisation of the Old Believers by the Mid-19th Century: The Origin of the Belokrinitskaya Hierarchy. Nasledie vekov - Heritage of Centuries. 4. pp. 66-72. (In Russian). DOI: 10.36343/SB.2019.20.4.008 